\title{
Lineament Domain of Regional Strike-Slip Corridor: Insight from the Neogene Transtensional De Geer Transform Fault in NW Spitsbergen
}

\author{
P. Cianfarra ${ }^{1}$ and F. SAlvini ${ }^{1}$
}

\begin{abstract}
Lineaments on regional scale images represent controversial features in tectonic studies. Published models explain the presence of the lineament domains in most geodynamic environments as resulting from the enhanced erosion along strikes normal to the upper crustal regional extension. Despite their success in many tectonic frameworks, these models fail to explain the existing lineament domains in the regional strike-slip corridors that separate regional blocks, including the transform faults. The present paper investigates the lineament distribution in such environments, and specifically presents the results from a study along the shear corridor of the De Geer Transform Fault in the North Atlantic, responsible for the separation and drifting away between Northern Greenland and the Svalbard Archipelago since Oligocene times. The study spans from satellite image analysis and outcrop scale investigations to a more regional analysis on a digital bathymetric model of the North Atlantic-Arctic Ocean. Lineaments were automatically detected in the spectral band $8(0.52-0.9 \mu \mathrm{m})$ of a Landsat 7 image $(15 \mathrm{~m} / \mathrm{pixel}$ resolution). A total of 320 image lineaments were extracted from both the regional and the local scale investigations and statistically analyzed. Results from the multi-scalar lineament analyses revealed the existence of a main $\mathrm{N}-\mathrm{S}$ lineament domain regionally persistent from the De Geer corridor to the western margin of northern Spitsbergen where it relates to the youngest, post-Oligocene, tectonics observed onshore. This is confirmed by field observations showing that the $\mathrm{N}-\mathrm{S}$ faults represent the youngest brittle deformation system and systematically cut the deformations associated with the building of the Tertiary West Spitsbergen fold and thrust belt. The N-S lineament domain is the result of the activity of a larger, regional scale tectonic feature, NW-SE oriented and responsible for the localized extension within its deformation corridor, the De Geer Transform Fault. A model is presented that involves the presence of a thin upper crust with brittle behavior lying above a deeper crustal layer characterized by a more ductile deformation. The lower layer suffers more diffuse, homogeneous strain. This strain is transmitted to the upper brittle layer, forming clusters of enhanced fracturing zones aligned following the induced stress trajectories. Lineaments develop along these weaker fractured zones, preferentially etched by erosional processes, and align perpendicular to the least horizontal compression (sigma3), which in turn forms an angle to the shear kinematics. In the western part of Spitsbergen, this angle is smaller than $45^{\circ}$ due to the transtensional tectonic regime. The
\end{abstract}

1 Science Dept., Università Roma Tre, L.go S.L. Murialdo, 1, 00146 Rome, Italy. E-mail: paola.cianfarra@uniroma3.it proposed model for lineament domain origin in strike-slip environments well integrates the existing models in literature and could be applied to other similar geodynamic contests.

Key words: Lineament domain, De Geer Transform Fault, Spitsbergen, regional strike slip corridor, arctic tectonics.

\section{Introduction}

Regional scale, sub-parallel linear topographic features characterize almost all planetary surfaces (HobBs 1904; WiSe 1969; WiSE et al. 1985 and references therein). Images of the Earth surface from space, available since the 1960 s, revealed the existence of linear patterns with dimension spanning over three order of magnitude: from hundreds of meters to thousands of kilometers. Synthetic scale images of the submarine environments showed that sub-continental sized linear features also characterize the seafloor. Such features are referred to "lineaments" (sensu WiSE 1969), and they are generally related to alignment of morphological/geological features in continental environments such as onshore crests, ridges, valleys and troughs. In the oceans, lineaments relate to the scars associated with the seafloor spreading, drifting, and fracture zones. Lineaments appear in the images as texture anisotropy and their photo interpretations suggest that they are generally related to tectonically controlled morphologies. Despite long lasting efforts, they still represent rather controversial features in tectonic studies. Many scientists unsuccessfully tried to directly frame these evanescent features into the classically known structural elements in geology, including regional faults, unconformities, dykes, as well as crustal discontinuities (e.g., Campbell 1987; Кoch and Mather 1997; 
Haeberlin et al. 2004; Gomez and Kavzoglu 2005; Solomon and Ghebreab 2006; Morelli and Piana 2006; PAL et al. 2006).

Systematic studies have been done in the past decades to understand the nature and origin of the lineaments (e.g., Wise 1967; 1969; Cardamone et al. 1976; Bodechtel and Munzer 1978; Salvini 1979; Wise et al. 1979, 1985; Norini et al. 2004; MorelLI and Piana, 2006; Pal et al. 2006), and showed that lineaments cluster around preferential orientations to form lineament domains. These sub-parallel populations, numbering in tens to hundreds, persist on regions spanning over thousands of square kilometers to form lineament swarms. WISE et al. (1985) suggested that lineament swarms originated through weathering and erosional etching of subtle features produced by extension of the brittle upper crust above a deeper layer behaving in a more ductile fashion. The proposed stress model assumes that the most prevailing lineament domain always lies perpendicular to the least horizontal compression responsible for its development (sigma3, sigma2 in compressional regimes, according to Anderson theory; e.g. DAvis and ReYNolds, 1996). In this way, lineaments may well be figured as the intersection with the topography of virtual vertical planar surfaces striking parallel to maximum horizontal compression (sigma1 or sigma2).

According to this model, the lineament analysis on synthetic scale images of the Earth surface revealed a useful tool to highlight the active/recent seismo-tectonics and volcano-tectonics in the various geodynamic environments (FunICIEllo et al. 1977; Wise et al. 1985; MAZZARini and SALVini 1994; Cianfarra and Salvini 2008; Pardo et al. 2009; GiORDANO et al. 2013; PischiUtTA et al. 2013; NoRini et al. 2004; PAL et al. 2006). Regional geodynamics is responsible for a series of effects that notably include tectonics and seismicity. They in turn control the morphology of the surface of the planet. Therefore, we expect different observable effects at the various scales from the outcrop evidences to the sub-continental deformation corridors in the various geodynamic settings. Different effects at the various scales are not necessarily directly related, and their relations should be carefully understood taking into account the responsible causes, their geometry, and spatial distribution. A classic example at the smaller scale is represented by an en-echelon system. Each single fracture is the effect of a local extension, yet their spatial distribution shows that these local stresses result from a larger scale shear zone with a different orientation.

Despite these results, there exist tectonic environments where the stress/strain orientation produced by tectonics is more complex and the proposed models are insufficient to explain the presence of lineament domains. A clear case is represented by the regional strike-slip corridors that separate regional blocks including the transform faults (e.g., MolnaR et al. 1999; SтоRті et al. 2003). These shear corridors are characterized by widths up to hundreds of kilometers as in the San Andreas fault system (Feigl et al. 1993; WaKabayashi 1999).

The present paper investigates the lineament distribution in such environments, and specifically presents the results from a multi-scalar study in the shear corridor of the De Geer Transform Fault in the North Atlantic, responsible for the separation and drifting away between Northern Greenland and the Svalbard Archipelago since Oligocene times (DALLMANN et al. 1993). In particular, this transform tectonics, coupled to vertical movements related to the glacial episodes, represents the main tectonic events that have been affecting Svalbard since Paleogene times (Tessensohn and Piepjohn 2000). Post-Oligocene tectonics in this region is characterized by faults and fractures (CIANFARRA and SALVINI 2013a), anomalously high uplift rates (GuEguen et al. 2003; KumAR and SingH 2012), quaternary volcanism (SkJelkVale et al. 1989; VÅgnes and AmundSEN 1993), as well as moderate seismicity (Mitchell et al. 1990). For these reasons, structural geology campaigns are still in progress in order to unravel the post-Oligocene to Recent tectonics in western Spitsbergen, the main island of the archipelago (CIANFARRA and SAlvini 2013a). Preliminary results from these campaigns revealed the presence of intense fracturing (including faulting) and deformation that also locally affect the moraine deposits. This brittle deformation might constitute the expected link between the presence of lineament domains in the surface and the tectonics in the area. The present study was concentrated over an area centered at the Brøggerhalvøya of 


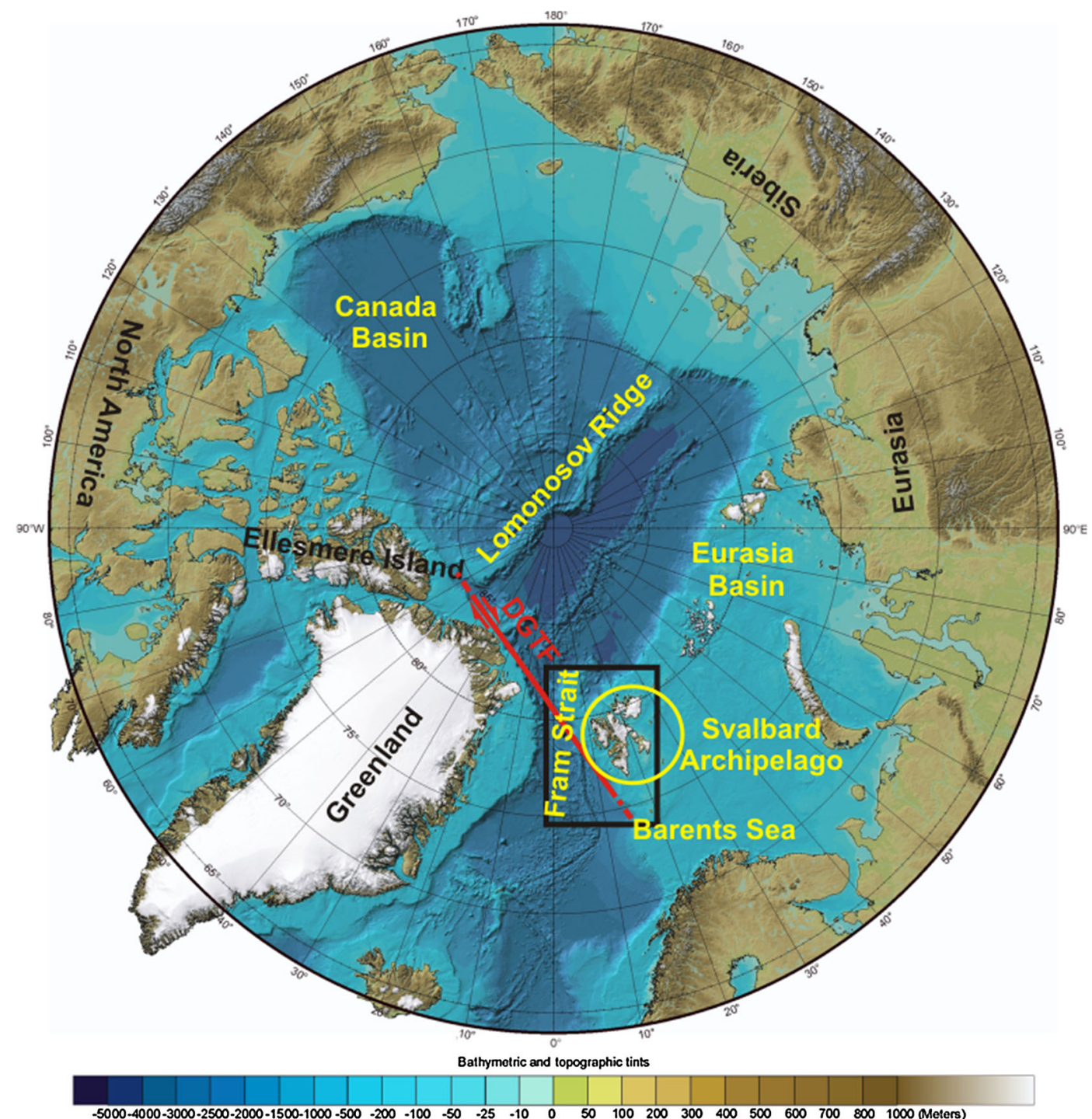

Figure 1

Location of the investigated area in the arctic region. Bathymetric data from JAKOBSSON et al. (2012). The rectangle marks the location of the regional scale lineament domain analysis of the bathymetric model of the North Atlantic where the De Geer Transform (DGTF) develops

Spitsbergen Island that is located some $150 \mathrm{~km}$ from the De Geer Transform and where intense brittle tectonic deformation has been documented (Fig. 1).

A lineament analysis of the Brøggerhalvøya has been progressed on satellite image and compared to the preliminary results of the structural field campaigns. Lineament analysis was done also in other three key areas around Brøggerhalvøya, and in the wider region including the bathymetry of the Northern Atlantic/Arctic Ocean where the De Geer Fracture Zone develops. This leads to the preparation of a specific model for lineament domain origin in strike-slip regimes that integrates the existing ones for the other geodynamic environments (WISE et al. 1985).

\section{Geological and Tectonic Setting}

The Arctic Ocean occupies a unique position at the junction of the major continental land masses of the Northern Hemisphere. Svalbard Archipelago 


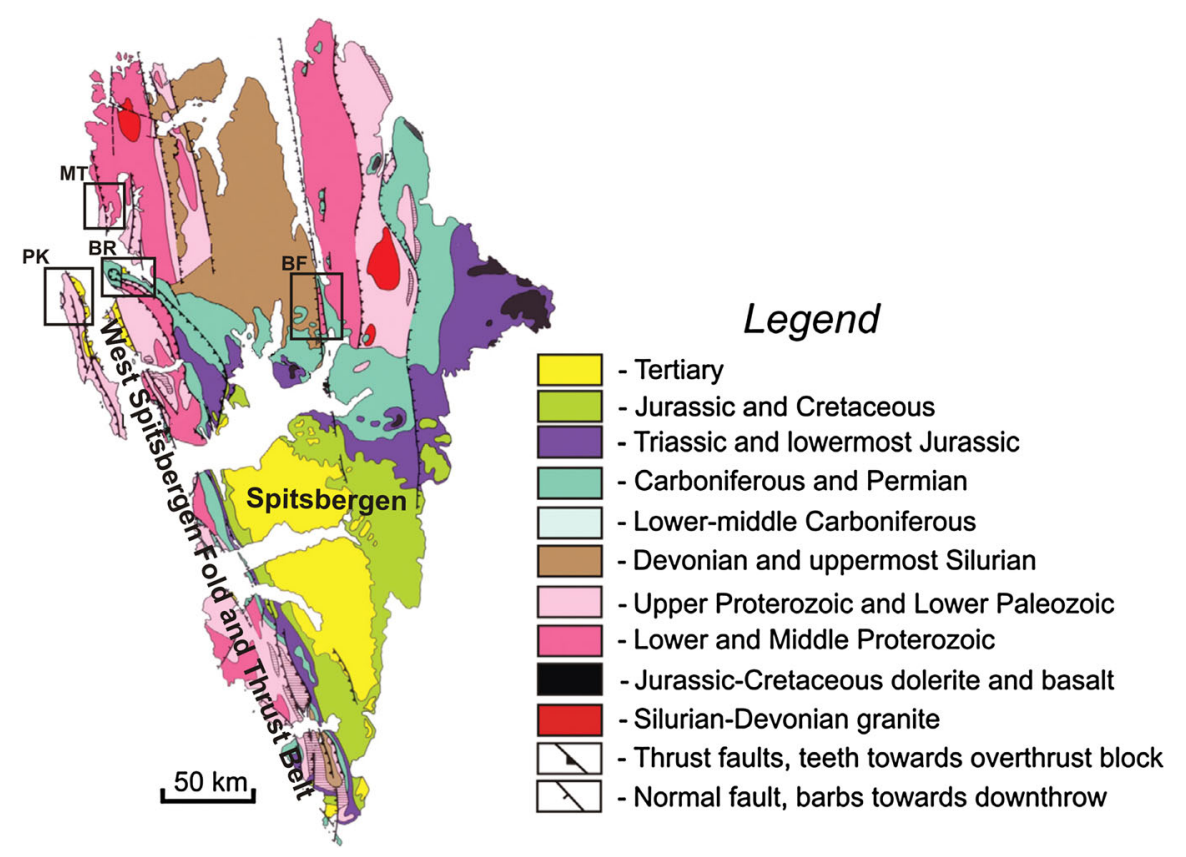

Figure 2

Simplified geological map of Spitsbergen, modified from HJelLE (1993). Rectangles show the location of the areas where lineament analyses were done on the Landsat 7 scene. $B R$ Brøggerhalvøya, $B F$ Billenfjord, $M T$ Mitrahalvøya, $P K$ Prince Karl Island

locates along the eastern sector of the De Geer Transform Fault that separates the kinematics of the North Atlantic and Arctic Ocean (Dallmann et al. 1993). Several investigations, helped by the extended rock exposures, allowed reconstruction of its main tectonic evolution (HARLAND 1997 and reference therein). The Tertiary West Spitsbergen fold and thrust belt (WSFTB) locates along the western part of Spitsbergen (Dallmann et al. 1993; Harland 1997) and its adjacent narrow continental shelf on the NW corner of the Barents Sea (Bergh et al. 1997). This orogenic belt is characterized by a length exceeding $500 \mathrm{~km}$ and a width of about $100 \mathrm{~km}$. The archipelago represents the northern uplifted and exhumed part of the Barents Sea continental shelf that preserves an onshore structural and stratigraphic record spanning from the Devonian to Cenozoic (Fig. 2; Dallmann 2007).

Plate drift resulting from post-Oligocene (postchron 13) oblique separation between Eurasia and Greenland (Talwani and Eldholm 1977; Tessensohn and Piepjohn 2000; Engen et al. 2008; Faleide et al. 2008) along the dextral De Geer Transform Fault led Svalbard to its present day position. The structuring of the western margin of Barents continental shelf involved the relative movements of Eurasia (to which Spitsbergen and the Barents Sea belong), Greenland and North America. Greenland was initially part of the Eurasia and became an independent microplate in the latest Paleocene (chron 24), when spreading started in the Norwegian-Greenland Sea. Since the earliest Oligocene (chron 13), after cessation of spreading in the Labrador Sea, the Greenland plate has moved with North America (GAINA et al. 2009; TAlwani and Eldholm 1977; Torsvik et al. 2001). Prior to and during the Cretaceous-Tertiary opening of the northern North Atlantic/Norwegian-Greenland Sea, Spitsbergen was attached to NE Greenland on the eastern side of the future transcurrent De Geer Zone (HARLAND 1969), which according to plate tectonic reconstructions accommodated about $750 \mathrm{~km}$ of along strike displacement during Eocene (GAINA et al. 2009).

Alternative hypotheses have been proposed to explain the evolution of the WSFTB and relate it to the activity of the transform fault. Since the 1960s, this fold-and-thrust belt was regarded as reflecting the contraction component of strain in a transpressional 
setting (Harland 1969; Lowell 1972; Faleide et al. 1988; MAHER and CRADDOCK 1988). This has been supported by analogue modeling performed by Leever and co-workers (LeEver et al. 2011). Hence, the fold-and-thrust belt was related to the evolution of the dextral transform fault system between Greenland and Svalbard (Harland 1969; SRIVASTAVA 1978; BirkenMaJer 1981; FALEIDE et al. 1993, 2008; LundiN and Dore 2002; Mosar et al. 2002; Gaina et al. 2009).

A slightly different hypothesis explains the evolution of the WSFTB as resulting from a head-on collision between the Greenland and the Eurasian plates (Lyberis and Manby 1993a, b; TesSENSOHN and Piepjohn 2000; CASE Team 2001; SaAlmann and ThIEDIG 2001). This model infers an earlier, Late Cretaceous-Paleocene age for the development of the WSFTB, which was questioned by MAHER et al. (1997) on the basis of contrasting field evidences. In the model of Lyberis and MAnBy (1993a, b), as well as in Tessensohn and Piepjohn (2000), strike slip occurred in a second, separate phase and was associated with the opening of the Norwegian-Greenland Sea.

A rather similar evolution has been advocated by SAalmann and Thiedig (2001), who, based on observations on Brøggerhalvøya, proposed separate stages of compression-dominated transpression followed by strike-slip dominated transpression. Hence, the compression of the fold belt occurred mainly before the strike-slip separation of Svalbard and the Barents shelf from Greenland. On the other hand, BERGH et al. (2000) interpreted the $\mathrm{N}-\mathrm{S}$ tectonics in Brøggerhalvøya as transfer faults active during the thrusting in Oligocene time. Despite the slightly differences in the interpretations of the earlier tectonic events, there is a general agreement that the last tectonic event in the region involves a dextral shear related to the De Geer Fracture Zone.

According to authors (BLyTHE and KLEINSPEHN 1998; Mitrovica et al. 1994), after the emplacement of the WSFTB, Spitsbergen has been mainly affected by post-glacial rebound processes. Nevertheless, evidence for younger tectonics includes the occurrence of Quaternary volcanism and thermal springs along N-S regional faults in the northern part of Spitsbergen (SKJElKVAle et al. 1989; VÅGNES and
Amundsen 1993; HJelle et al. 1999) and the existence of moderate to strong magnitude earthquakes (Mitchell et al. 1990). Gueguen et al. (2003) and Kumar and Singh (2012) have found in the NW Svalbard (Ny Ålesund) an uplift rate from geodetic measurements (above $6 \mathrm{~mm} /$ year) higher than those predicted by post-glacial rebound models (lower than $2 \mathrm{~mm} /$ year, Mitrovica et al. 1994; Soudarin et al. 1999; HaAs et al. 2000), and suggested a tectonic contribution related to active/recent faults in the Brøggerhalvøya.

\section{Lineament Analysis Methodology}

Lineament domain analysis was progressed on a subset of a Landsat 7 image ( $24 \mathrm{~km}$ wide by $20 \mathrm{~km}$ high) including the key area of the Brøggerhalvøya (location in Fig. 2). This area was chosen because it is characterized by the presence of intense tectonic deformation related to the strike slip regime ruling the Cenozoic geodynamics between northern Greenland and Svalbard archipelago (HARLAND 1997). Furthermore, geodetic surveys in this peninsula raised the hypothesis of a recent tectonic contribution to the measured vertical movement (GUEGUEN et al. 2003; Kumar and Singh 2012). Three other areas around the Brøggerhalvøya were studied by lineament domains analysis to integrate results, and compared to strengthen the consistency and the regional meaning of the found lineament domains. These areas from the same Landsat 7 scene (location in Fig. 2) include the Northern Prince Karl Island to the West ( $35 \mathrm{~km}$ wide by $40 \mathrm{~km}$ high), the Mitrahalvøya to the North (31 km wide by $31 \mathrm{~km}$ high), and the Northern Billenfjord to the East $(36 \mathrm{~km}$ wide by $42 \mathrm{~km}$ high). Furthermore, a more regional scale lineament analysis on a subset $(750 \mathrm{~km}$ wide by $750 \mathrm{~km}$ high along the false Easting and Northing at $0^{\circ} \mathrm{E}$ ) of the digital bathymetric model of the Northern Atlantic-Arctic Ocean (JAKOBSSON et al. 2012) was done to characterize the tectonic setting along the De Geer Fracture Zone. Lineaments from the Brøggerhalvøya were compared with field structural data measurements to explore the relation between the presence of lineaments at the surface and the brittle tectonics of the area. 
Lineament detection differs from most other kind of geological observations in the magnitude of its potential for observer bias (WISE, 1982). In fact, manual lineament identification may be conditioned by psychological factors of operator as enthusiasm for drawing lines or former knowledge of the study area that can produce a biased data set. To overcome this problem, various computer aided lineament extraction procedures have been developed. Proposed methodologies span from the search for well defined, not necessarily linear, discontinuities (e.g., GioRdano et al. 2013), as proposed in some commercial software (i.e., continuous and preferred orientation of image aspect/slope), to the identification of subtle, yet long and linear, features as in the method used in the present study (e.g., PARdo et al. 2009).

A bias is also produced by the lighting conditions, which tend to hide lineaments that lie nearly parallel to the lighting direction. This produces an asymmetry in the azimuthal lineament frequency that is responsible for an apparent rotation of their mean values away from the lighting conditions. This rotation can be up to about $10^{\circ}$ and depends on the combination of lighting conditions and morphological contrast (WISE 1969). This effect must be taken into consideration when comparing lineament domain azimuths with the tectonics of the studied area. The use of shadowed images of the surface morphology according to various lighting conditions will easily suppress this bias (WISE et al. 1985). On the other hand, existing DEMs do not have the vertical resolution required to render the smoothest details that form many of the faint lineaments that are clearly detectable on satellite images (yet are possibly slightly rotated). For the purpose of this study, and considering the tectonic environment of Svalbard since post-Oligocene times, we mainly focused the study on a satellite image, carefully taking into account the small rotations expected of morphology-related lineaments. Furthermore, a lower spatial resolution $(1 \mathrm{~km} /$ pixel) more regional scale digital bathymetric model of the Northern Atlantic, where the De Geer Transform develops, was analyzed for lineament detection.

Satellite lineaments from the Brøggerhalvøya, the Northern Prince Karl Island, the Mitrahalvøya, and the Northern Billenfjord were automatically detected in the panchromatic spectral band $8(0.52-0.9 \mu \mathrm{m})$ of a Landsat 7 image ( $15 \mathrm{~m} /$ pixel resolution) by the SID software (Cianfarra and SALvini 2008). The automatic detection prevented any possible bias induced by manual tracing. The analyzed image was acquired on 10 July 1999 and downloaded for free at http://glcfapp.glcf.umd.edu:8080/esdi/. The SID software finds out alignment of adjacent pixel contrasts in raster images by a systematic search for all possible digital combinations of segment directions within a given range of parameters, including size and definition. The characteristic of this algorithm is that the search for pixel alignments is not restricted to adjacent pixels. In this way, it is possible to also detect faint, discontinuous lineaments. The main parameters defining the characteristics of the image lineaments to drive the software on lineament finding are: the minimum and maximum length in pixel unit of a lineament; the width of lineament measured in pixel unit perpendicularly to its strike; the dimension of the moving smoothing window along the potential lineament to override the discontinuities in pixel distribution; the minimum length of each lineament segment; the maximum distance between lineament segments that belong to the same lineament; and the pixel density along the lineaments. In this study, a set of parameters was arranged to find out lineaments longer than $3 \mathrm{~km}$ and $90 \mathrm{~m}$ wide in the four studied areas from the Landsat 7 image. Image lineaments longer than 50 and $3 \mathrm{~km}$ wide were identified in the more regional scale analysis of the bathymetry along the De Geer Transform in the Northern Atlantic. This choice of SID parameters was used in order to identify only lineaments with regional dimension, tectonic meaning, and crustal importance, which are lineaments that are relevant for the comprehension of the geodynamics of the investigated area.

The ad hoc image processing was applied to the panchromatic band of the Landsat image for lineament enhancing (Cianfarra and Salvini 2008). This processing included the sub-setting of the four analyzed areas, high-pass spatial frequency filtering, and threshold slicing. Eventually the Life filtering was used to clean images from meaningless, isolated pixels. The Life filter compares each significant pixel (i.e., DN value higher than the threshold slicing) with its surrounding ones and clears it if the number of 


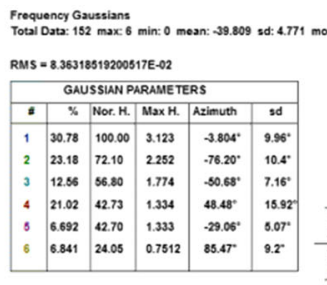

a

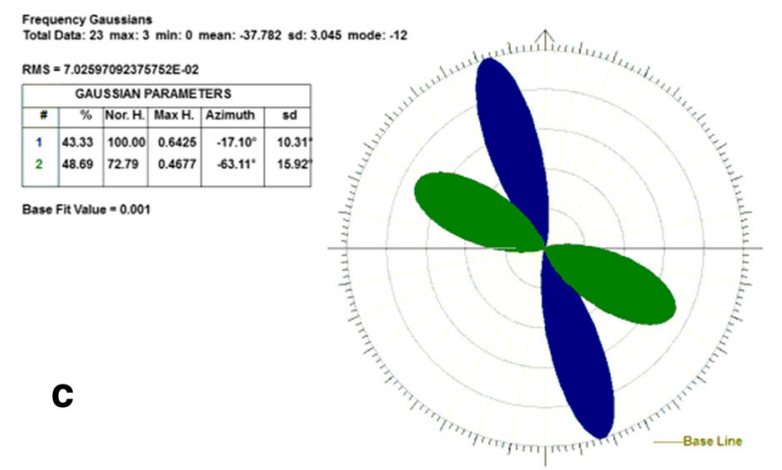

Frequency Gaussians
Total Data: 62 max 7 min

RMS $=0.120859299984196$

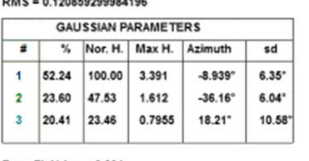

Base Fit Value $=0.001$

\section{e}

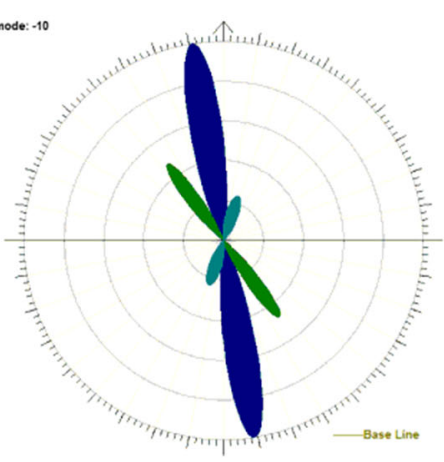

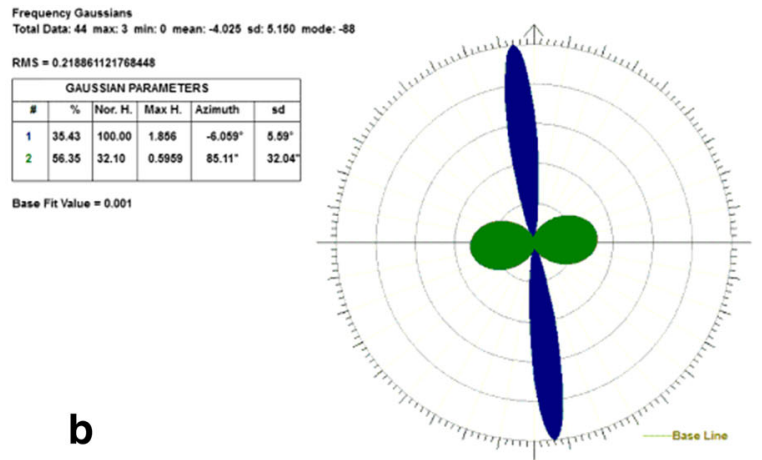

Frequency Gaussians
Total Data: 39 max 3 min: 0 mean: 92.459 sd: 4.763 mode: -80
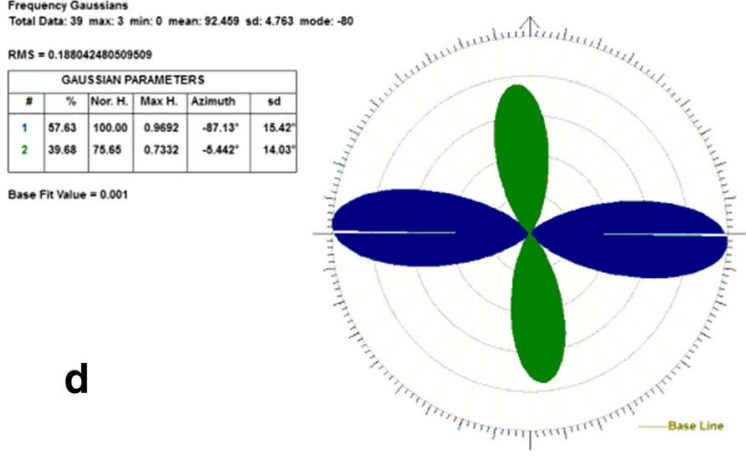

Figure 3

Polymodal Gaussian fit of the automatically detected lineaments from the four subsets of the spectral band $8(0.52-0.9 \mu \mathrm{m})$ of satellite Landsat 7 image and from the more regional scale analysis of the digital bathymetry of Northern Atlantic. a Brøggerhalvøya; b Mitrahalvøya; c Prince Karl Island; d Billenfjord; e Northern Atlantic digital bathymetry

significant surrounding pixels is below a given threshold (four in the present analysis). Image processing of the subset of the digital bathymetric model of the North Atlantic included the preparation of four shadowed images according to synthetic lighting directions from N, NE, E and SE, thus replicating the technique initially proposed by WISE (1969). These shadowed images were then filtered by means of lowpass filters to suppress the morpho-bathymetric variations with wavelengths smaller than $3 \mathrm{~km}$ related to local scale factors. Then high-pass spatial filtering, threshold slicing and Life filtering were applied.

Image lineaments extracted from each subset were cumulated into databases and successively statistically analyzed by the Daisy software (freely distributed at http://host.uniroma3.it/progetti/fralab; Fig. 3; SAlvini et al. 1999). Azimuthal frequency 



Figure 4

Results of the automatic lineament analysis from the spectral band $8(0.52-0.9 \mu \mathrm{m})$ of satellite Landsat 7 image. a Spatial distribution over Brøggerhalvøya of the identified lineaments; $\mathbf{b}$ spatial distribution of the N-S lineament domain; $\mathbf{c}$ spatial distribution of the NW and WNW domains; d location of the sites for structural field measurements

analyses for each subset were progressed according to the technique proposed in WISE et al. (1985), which included their polymodal Gaussian fit to identify lineament domains.

\section{Lineament Analysis Results}

Analysis of the Brøggerhalvøya shows that the 152 automatically detected lineaments cluster in azimuthal sets, the domains, and are characterized by a mean length of 3,970 m (Figs. 3, 4). The main lineament domain is oriented $\mathrm{N}-\mathrm{S}\left(\mathrm{N} 4^{\circ} \mathrm{W} \pm 8^{\circ}\right)$.
Two other meaningful close domains exist, the WNW $\left(\mathrm{N} 75^{\circ} \mathrm{W} \pm 9^{\circ}\right)$ and the $\mathrm{NW}\left(\mathrm{N} 52^{\circ} \mathrm{W} \pm 6^{\circ}\right)$. The ratio NorH/SD between the relative height (NorH in the table of Fig. 3a) and the SD of each Gaussian peak represents its sharpness and is a parameter to evaluate the relative youth of the lineament domains, since it indicates the azimuthal scattering of lineaments with respect to their number (SALVINI et al. 1979). The main $\mathrm{N}-\mathrm{S}$ peak has the highest NorH/SD value of 12.2, compared to values of 6.8 and 8.7 for the other WNW and NW domains. This suggests that the prevailing $\mathrm{N}-\mathrm{S}$ domain represents the youngest lineament population and relates to the most recent 
tectonics in the studied region. Lineaments of the main $\mathrm{N}-\mathrm{S}$ domain spatially concentrate along the main glacier drainage network, where it shows a complex pattern with a strong $\mathrm{N}-\mathrm{S}$ trend. This suggests the possible tectonic control on the glacier drainage (Fig. 4b). Lineament spatial distribution of this domain shows a rather regular left-step, en-echelon pattern with an average step of about 2,500 m. On the other hand, the WNW and NW domains show a rather uniform spatial distribution throughout the peninsula (Fig. 4c).

The mean length of the 44 lineaments detected from the Mitrahalvøya is $3,990 \mathrm{~m}$. Two main lineament domains were identified, the main one is $\mathrm{N}-\mathrm{S}$ trending $\left(\mathrm{N}^{\circ} \mathrm{W} \pm 6^{\circ}\right)$ and the second is WNW trending $\left(\mathrm{N} 85^{\circ} \mathrm{E} \pm 32^{\circ}\right)$. The NorH/SD values are 17.9 and 1.0 for the main $\mathrm{N}-\mathrm{S}$ and the second WNW peak, respectively. The lineament analysis of the Northern Prince Karl Island showed that the 23 identified lineaments, with a mean length of $3,750 \mathrm{~m}$, cluster into two domains; the main one is $\mathrm{N}-\mathrm{S}$ trending $\left(\mathrm{N} 17^{\circ} \mathrm{W} \pm 10^{\circ}\right)$ with a NorH/SD value of 9.7, and the minor one is $\mathrm{WNW}$ trending $\left(\mathrm{N} 63^{\circ} \mathrm{E} \pm\right.$ $16^{\circ}$ ) and is characterized by a NorH/SD ratio of 4.6. Lineament analysis of the easternmost investigated area from Brøggerhalvøya, namely the Billenfjord, revealed the existence of two main lineament domains from the 39 identified lineaments (mean length of 3,690 m). The main peak is WNW trending $\left(\mathrm{N} 87^{\circ} \mathrm{W} \pm 15^{\circ}\right)$ with a NorH/SD value of 6.5 , and the second one is $\mathrm{N}-\mathrm{S}$ trending $\left(\mathrm{N} 5^{\circ} \mathrm{W} \pm 15^{\circ}\right)$ with NorH/SD of 5.3. Lineaments from the more regional scale, lower spatial resolution, analysis of the digital bathymetry subset of the Northern Atlantic revealed the existence of 62 lineaments with a mean length of $70.5 \mathrm{~km}$ that cluster into three domains. The main one is oriented $\mathrm{N}-\mathrm{S}\left(\mathrm{N} 9^{\circ} \mathrm{W} \pm 6^{\circ}\right)$ and the two subordered $\mathrm{N} 36^{\circ} \mathrm{W} \pm 6^{\circ}$, and $\mathrm{N} 18^{\circ} \mathrm{E} \pm 11^{\circ}$, respectively. The highest NorH/SD value of 15.7 characterizes the $\mathrm{N}-\mathrm{S}$ main peak. Please note that these directions have been corrected and referred to the central meridian of the Landsat image $\left(15^{\circ} \mathrm{E}\right)$ for the proper azimuthal comparison due to the polar location of the investigated region.

To sum up, these further analyses confirmed results from the Brøggerhalvøya. The $\mathrm{N}-\mathrm{S}$ lineament domain is the main Gaussian peak in four out of the five investigated areas, both at the regional and at the local scale. This $\mathrm{N}-\mathrm{S}$ domain is always characterized by the highest NorH/SD value, suggesting its relatively youngest age compared to the other found lineament domains. The proposed genetic relative chronology of the found lineament domains allows one to relate the $\mathrm{N}-\mathrm{S}$ domain to the most recent tectonics that affected the western Spitsbergen, namely the ongoing shearing and stretching along the De Geer strike slip corridor. The $\mathrm{N}-\mathrm{S}$ lineament domain is still present, yet is the second peak in the analysis of the Billenfjord area, with a NorH/SD value comparable to the corresponding one of the local main peak. This may relate to the location of the Billenfjord, about $300 \mathrm{~km}$ away from the De Geer Transform, farther from the influence of its diffuse deformation zone than the other on-land investigated areas (located between 100 and $150 \mathrm{~km}$ from the transform). The field observations, as discussed in the next chapter, confirm the importance of the $\mathrm{N}-\mathrm{S}$ fracture system in Brøggerhalvøya at the outcrop scale of investigation.

\section{Comparison with Structural Field Data Analysis}

A series of structural data investigations were done to compare and constrain the lineament analysis within the post-Oligocene tectonic setting of the Brøggerhalvøya and its framing to the regional (plate) tectonic setting, including the De Geer corridor. The study consisted in the identification of field sites of measurements of the tectonic elements that could be reconducted to Late Cenozoic-Recent surficial tectonic activity, such as brittle fracturing, including extensional fractures (joints), faults. The attitude and spatial distribution of these elements was compared to the results from the lineament analysis to identify possible azimuthal correlations between these two sets of data, characterized by dimensions of different orders of magnitude.

Structural data were collected during a series of short field campaigns in the Northern Spitsbergen in the last decade within a research project aimed to investigate on the possible presence of NeogeneQuaternary tectonics of the region (CIANFARRA and SALVINI 2013a). During these campaigns, a series of ad 


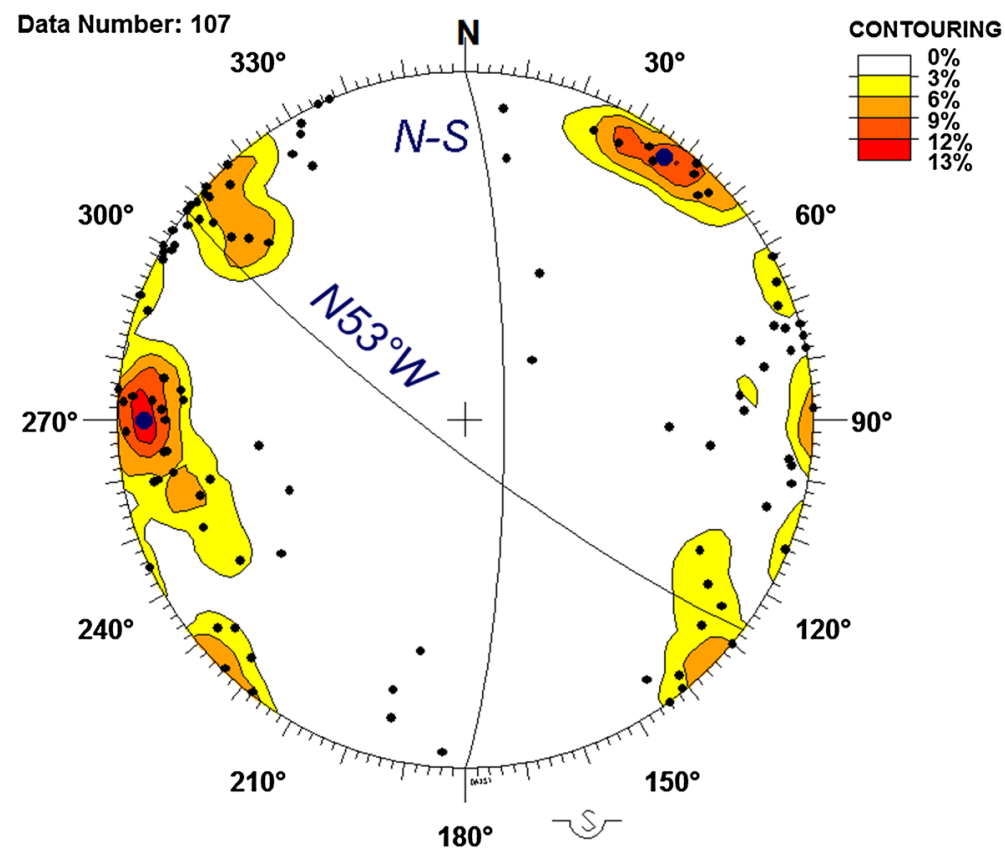

Figure 5

Projection of contouring of poles (black dots) to brittle deformation data (Schmidt Net, lower hemisphere) from field sites showing the main $\mathrm{N}-\mathrm{S}$ fracture population and the sub ordered $\mathrm{N} 53^{\circ} \mathrm{W}$ one. Larger dots represent their mean pole attitudes

hoc field sites of structural measurements were done for the comparison and ground truth of the satellite image lineament analysis. Site locations for this study were chosen on the basis of their close geographic relations with the found lineament domains.

A total of 107 structural data from six sites in Brøggerhalvøya were collected and include joints, minor faults, either normal, reverse, or strike-slip, and associated brittle deformations as fracture cleavages, either shear or pressure solution. The term fracture cleavage is here referred to a fracture set characterized by spacing significantly shorter than the single fracture dimension. Dimensions of most of the observed elements range from $10 \mathrm{~cm}$ to several meters, with maximum dimension limited by the outcrop size, often heavily reduced by the ice cover (Fig. 4d). Brittle deformation data were collected in rocks with ages ranging from Middle Proterozoic to Paleocene and Quaternary marine shore and fluvial deposits (HJelle et al. 1999).

All the collected brittle deformations were analyzed without considering their origin or type, even if this information was recognized in the field and recorded. This grouping was intentionally followed due to the purpose of the present work, aimed to relate surface expressions as the lineament domains to crustal stresses. All open brittle deformations contribute to weakened rock rheology, and therefore enhance the modeling capability of erosional processes. Attitudes of structural data were analyzed by contouring their projection on a Schmidt Net (lower hemisphere, Fig. 5). The contouring shows the presence of two main clusters of near-vertical fracture sets. The main one has an average $\mathrm{N}-\mathrm{S}$ azimuth and the second one has an average azimuth of $\mathrm{N} 53^{\circ} \mathrm{W}$.

Field observations confirmed that the N-S faulting offsets the other fracture systems related to the Paleocene-Oligocene thrust and fold tectonics and therefore it represents the effects of the youngest tectonics affecting the area. Furthermore, the N-S fracture system maintains its strike all over the field investigated area, independently from the rotation of the structure axis. The presence of $\mathrm{N}-\mathrm{S}$ faulting is in agreement with the authors (HJELle et al. 1999; MAHER et al. 1997; BERGH et al. 2000; SAALMANN and THIEDIG 2001), even if with different interpretations.

Field investigations showed the presence of $\mathrm{N}-\mathrm{S}$ step alignments in the marine terraces and fluvio- 
glacial deposits. Those steps locates along the northern projection of both measured or referenced (BERgh et al. 2000; SAALMANN and ThIEDIG 2001) N-S trending faults cutting the Brøggerhalvøya structures. The structural/tectonic control on the landscape is also testified by the $\mathrm{N}-\mathrm{S}$ and $\mathrm{E}-\mathrm{W}$ zigzagging trajectory of the northeastern shoreline and by the topography of the Brøggerhalvøya (Fig. 4d). A similar influence of the $\mathrm{N}-\mathrm{S}$ tectonic trend on the landscape is testified by the complex, trellis-shaped drainage trajectory of glaciers on the NE side of the Brøggerhalvøya (Tolgensbakk and Sollid 1987), where glaciers form a puzzling network (Fig. 4d), as proposed in the lineament analysis. $\mathrm{N}-\mathrm{S}$ faults are also reported in the Loven Islands in the Kongsfjord (HJElle et al. 1999). Preliminary results from morpho-bathymetric investigations in the Kongsfjord by chirp seismic sounding (Aliani et al. 2012; DeL BiAnco et al. 2013) revealed a $\mathrm{N}-\mathrm{S}$ trending morphological grain associated to sharp $\mathrm{N}-\mathrm{S}$ vertical steps in the internal seafloor of the fiord. All these evidences confirm the hypothesis that the observed $\mathrm{N}-\mathrm{S}$ trending brittle deformation (fault and fracture systems) represents the prevailing and youngest tectonic grain of the region affecting its offshore and onshore post-glacial morphological evolution.

The two main fracture sets, N-S and $\mathrm{N} 53^{\circ} \mathrm{W}$, correlate to the main lineament domains found in the Brøggerhalvøya, namely the main $\mathrm{N}-\mathrm{S}$ domain and the more scattered NW to WNW one. The found azimuthal correspondence confirms the origin of lineament domain as the result of the interaction between acting stresses and the preferentially oriented landscape modeling by the development of diffuse, minor fractures. This contrasts with the common belief on a direct correspondence of lineaments to single, regional scaled structural elements (e.g., faults, dykes). The spatial clustering of the N-S lineament domain has been found also in the field structural data, with higher intensity of brittle deformations in corresponding narrow bands.

\section{Proposed Tectonic Model}

The lineament analysis showed the presence of a prevailing $\mathrm{N}-\mathrm{S}$ domain that is regionally developed both within the Brøggerhalvøya and within the western margin of northern Spitsbergen, as well as in the De Geer corridor. This $\mathrm{N}-\mathrm{S}$ domain persists also further to the $\mathrm{E}$, yet locally sub ordered to a nearly $\mathrm{E}-\mathrm{W}$ domain. The spatial distribution in Brøggerhalvøya of the $\mathrm{N}-\mathrm{S}$ domain shows a characteristic clustering into narrow zones with a left-step along a NW-SE elongated zone that rather coincides with the peninsula.

According to the lineament domain theory (WISE et al. 1985), the found $\mathrm{N}-\mathrm{S}$ lineament domain indicates an upper crustal extension along an E-W direction. The found en-echelon spatial distribution along a NW-SE trend indicates that this extension may be the result of the activity of a parallel tectonic feature at the larger regional scale (CIANFARRA and SALVINI 2013b). This element can easily be responsible for the localized extension, assuming that it has a right-lateral shear component (Fig. 6). This kinematics would produce the internal, E-W extensional regime of stress expected within the NW-SE shear corridor (HARDING 1985). In pure strike-slip corridors (including transform faults), the stresses induced by the kinematic conditions have the minimum (as well as the maximum) principal stress component at $45^{\circ}$ from the main fault orientation and the intermediate stress lies vertical (Fig. 6). In the presence of a transtensional (transpressional) regime (RossetTI et al. 2000), either related to a bend in the main fault trajectory or to a local change in the block kinematics, this angle decreases (increases) until it becomes parallel (normal) to the main fault in the case of pure extensional (compressional) kinematics. The presence of en-echelon, sub-ordered elements along major strike-slip faults has been reported also at the local scale (Pischiutta et al. 2012; SALVini et al. 1999).

A plate tectonic margin with right-lateral strikeslip shear zone is well known and active in the region. This is the aforementioned De Geer Fracture Zone, which runs along a NW-SE trend West of Spitsbergen with a possible associated shear zone and secondary branches, as observed in other similar tectonic environments such as the San Andreas fault system (e.g., WaKabayashi 1999; Turcotte and Schubert 2002). At the Svalbard geographic location, the De Geer Fracture Zone has a strike of $\mathrm{N} 30^{\circ} \mathrm{W}$ 


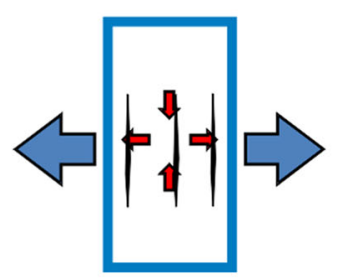

a

EXTENSIONAL FAULT KINEMATICS

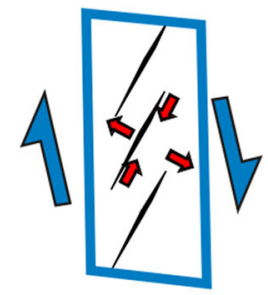

b

TRANSTENSIONAL FAULT KINEMATICS

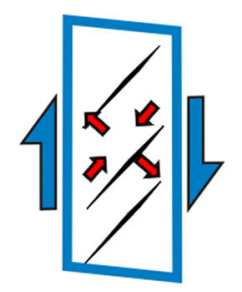

C

STRIKE-SLIP FAULT KINEMATICS

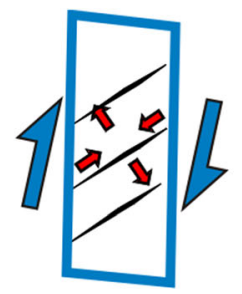

d

TRANSPRESSIONAL FAULT KINEMATICS

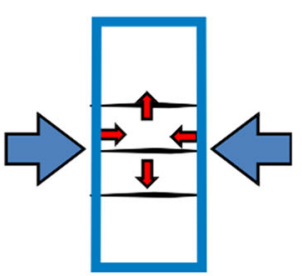

e

COMPRESSIONAL

FAULT KINEMATICS

\section{Figure 6}

Rotation of intra-fault corridor stress field and related lineament domain as resulting from the fault kinematics. Blue arrows indicate the relative movement between the blocks divided by the fault plane. Red arrows indicate the orientation of the maximum (converging arrows) and minimum (diverging arrows) strain/stress principal components (assumed co-axial, where positive strain indicate shortening) inside the fault zone. Black lines indicate expected lineament domain orientation. In pure strike-slip faults (c) the maximum principal stress (sigma1) develops at $45^{\circ}$ from the fault plane. In transtensional fault kinematics (b) this angle decreases and is $<45^{\circ}$, and reduces to $0^{\circ}$ in pure extensional fault kinematics (a). In transpressional faulting (d) this angle increases and is $>45^{\circ}$, and becomes $90^{\circ}$ for pure compressional kinematics (e). Examples are for right-lateral kinematics. Specular setting results from left-lateral kinematics

forming an angle with the lineament domain smaller than $45^{\circ}$. According to what discussed before, this small angle may results partly from the lighting effect (which can bias the analysis for no more than few degrees) and mostly from the transtensional regime in the shear corridor between Northern Greenland and Svalbard since Oligocene time (Dallmann et al. 1993).

These considerations allow us to frame the described tectonic setting into a lineament domain origin model that integrates the models presented in WISE et al. (1985) for strike-slip geodynamic environments (Fig. 7). This model applies to strike-slip corridors between adjacent crustal blocks (including plate margins) as the transform faults. It involves the presence of a thin upper crust with brittle behavior lying above a deeper and thicker crustal layer characterized by a more ductile deformation. The lower layer deforms with a rather diffuse, homogeneous strain. This strain is transmitted to the upper more brittle layer forming clusters of enhanced fracturing zones aligned and following the induced stress trajectory. Lineaments will develop along these weaker fractured zones preferentially etched by erosional processes, and also due to fluid interactions (MAGGI et al. 2014). In this way, lineaments will align perpendicular to the least horizontal compression (sigma3 in our model). The proposed model has strong analogies with en-echelon fracture systems at the smaller scale, where a


Figure 7

Tectonic setting and stress field for lineament domains in strike-slip (transform) fault corridors. The model refers to pure right-lateral kinematics. Left-lateral kinematics produces a specular setting

stepped extensional fracture set develops in a shear zone in semi-ductile environment, due to the internal, kinematic-related stress (e.g., RAMSAY and HubER 1983).

The structural field investigations confirmed the presence of the spatially clustered $\mathrm{N}-\mathrm{S}$ trend. The small observed azimuthal divergences among the various sets of data (i.e., lineaments from satellite image, digital bathymetry, and structural data) are 


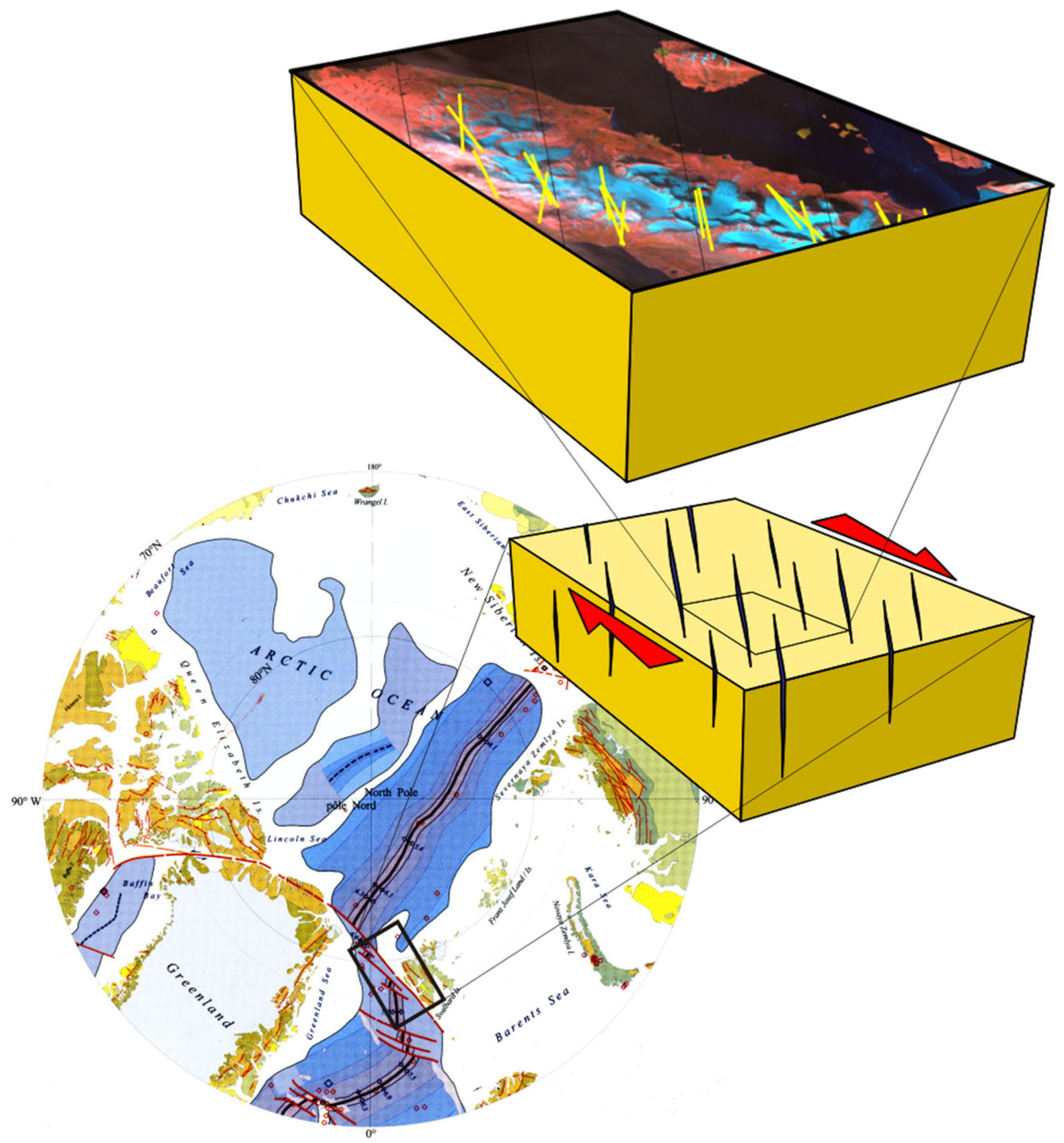

Figure 8

Proposed sheared geodynamic setting for the western margin of Spitsbergen related to the SE projection of the De Geer Transform Fault and its shear corridor. Lower image redrawn from the seismotectonic map of the World 1:50,000,000 CGMW/UNESCO, 2001

within their SD (Figs. 3, 5), and may partly relate to the subset of lineaments observed in a single lighting condition image as previously discussed (i.e., the used satellite image; see WISE 1969; WISE et al. 1985).
The relation between the found lineaments and the structural data in the field confirms the model for lineament origin. They form where weathering and erosional processes preferentially etch the tectonically controlled landscape. In this way, there is not a 
direct correlation between lineaments and type of brittle deformation that concur to develop the lineament itself. The contribution of different families of joints and faults, where the tectonic processes strongly influence the modeling agents, creates the corridors where lineaments will develop. Typically, the most recent tectonics plays this role, being responsible for the main structural grain of the upper brittle crust both inland and in the sea floor.

Results from this study confirmed that the geodynamics of the region are ruled by the interaction between the Greenland and Eurasian plates, whose relative movements produce stretching and shearing along their plate boundaries, including transtensional tectonics along the De Geer Fracture Zone in post-Oligocene times. Its shear zone extends laterally up to the western coasts of Spitsbergen in a scenario similar to that proposed by the authors (e.g., Storti et al. 2003; Dubbini et al. 2010; CianFARRA and SAlvini 2013b). This differs from the general knowledge on transform faults, which considers them as merely passive dislocations that accommodate relative movements between offset ridge segments in ocean plate regions. The De Geer Transform Fault associates to this task an anomalously wide shear zone at the Spitsbergen latitudes. This leaves open the hypothesis that at least a segment of this transform propagates to the SE along the western coasts of Spitsbergen with an extra, right-lateral transtensional kinematics within this margin of the continental Eurasian Plate (Fig. 8). A similar tectonic scenario was proposed by $\mathrm{S}_{\mathrm{ALVINI}}$ et al. (1997) and SтоRTi et al. (2007) to explain the southward propagation of the Balleny and Tasman fracture corridors from the Southern Ocean to the Ross Sea and Northern Victoria Land (East Antarctica) along shear corridors characterized by width of the order of hundreds of kilometers. The presence of the N-S domain on the oceanic crust with ages much younger than the development of the WSFTB confirms that this domain is not associated with the brittle deformations of the belt. Eventually, this spatial distribution precludes to relate the development of the $\mathrm{N}-\mathrm{S}$ domain to extension processes localized at Svalbard and successive to the WSFTB formation, as suggested by VÅGNES and AMUNDSEN (1993).

\section{Conclusions}

This paper deals with the occurrence of lineament domains within geodynamic environments characterized by strike-slip deformation corridors. This task was focused on the western part of Spitsbergen Island, where the last tectonic activity since Late Cenozoic times is controlled by the De Geer Transform Fault and its associated shear zone, which displaces the Greenland versus the Eurasian plates with a right-lateral sense of movement. Lineaments were detected by an automatic procedure focused on the identification of faint and long lineaments. This proved a necessary and useful tool to identify crustal scale lineaments and to prevent their analysis from subjective bias.

Results from the multi scalar lineament analyses revealed the existence of a persistent $\mathrm{N}-\mathrm{S}$ lineament domain regionally developed from the De Geer corridor to the western margin of northern Spitsbergen, where it relates to the youngest, post-Oligocene, tectonics observed onshore. This tectonics may produce either the (neo)formation of weaker, more brittle deformation zones, preferentially etched by erosional processes, or reactivate ancient crustal weaknesses along the N-S pathways to form the observed persistent lineament domain. In this way, the tectonic meaning of the present-day N-S lineament domain is independent from the previously proposed interpretations of the $\mathrm{N}-\mathrm{S}$ faulting in the area. The proposed new model successfully explains the lineament domain origin in this strike-slip geodynamic setting. A lineament domain develops in the upper brittle crust within the shear zone corridor due to the internal stress induced by the regional fault kinematics. They strike perpendicular to the least horizontal compression axis of the resulting stress. In this way, the lineament domain forms a characteristic angle to the regional fault. This angle is $45^{\circ}$ in pure strike-slip block movements, and decreases when a transtensional component exists, as in the Spitsbergen western margin.

The proposed model for lineament domain origin in strike-slip environments well integrates the existing models in literature and could be applied to other similar geodynamic contests. Lineament domains, although visible only at the regional scale with faint 
evidence, represent structural elements with defined relationships with the tectonic environments. They have been revealed to be part of the structural pattern that characterizes the deformation zones of strike-slip faults.

This study was limited to the NE side of the De Geer Transform Fault. Further evidence would come by comparison with a similar investigation in Northern Greenland, where the onshore SW side of this fault outcrops. This will contribute to clarifying the evolution of the puzzling connection between Greenland and the Lomonosov Ridge, whose presentday separation lies on the NW prosecution of this fault.

\section{Acknowledgments}

The fieldwork benefitted of facilities provided by the CNR-Base Dirigibile Italia at Ny Ålesund. The authors are indebted both to the CNR and to its personnel at the base.

Open Access This article is distributed under the terms of the Creative Commons Attribution License which permits any use, distribution, and reproduction in any medium, provided the original author(s) and the source are credited.

\section{REFERENCES}

Aliani S., Giglio F., Langone L., Miserocchi S., Del Bianco F. (2012), Banchi alla deriva nel Mare Artico, Darwin 47, 62-67. http://www.darwinweb.it.

Bergh S.G., Brathen A., Andresen A. (1997), Interaction of basement-involved and thin-skinned tectonism in the Tertiary fold-thrust belt of central Spitsbergen, Svalbard. AAPG Bulletin 81, 637-661.

Bergh S.G., Harmon D. JR, BraAthen A. (2000) Tertiary divergent thrust directions from partitioned transpression, Brøggerhalvøya, Spitsbergen. Norsk Geologisk Tidsskrift 80, 63-81.

BirkENMAJER, K. (1981), The geology of Svalbard, the western part of the Barents Sea, and the continental margin of Scandinavia, In The ocean basins and margins (A.E.M. Nairn et al. eds.) (New York: Plenum Press).Vol. 5. The Arctic Ocean. pp. 265-329.

Blythe, A. E., Kleinspehn, K. L. (1998), Tectonically versus climatically driven Cenozoic exhumation of the Eurasian plate margin, Svalbard: Fission track analyses. Tectonics 17, 621-639.

Bodechtel, J., and Munzer, U. (1978), Satellite lineaments of the central Mediterranean region (Sicily/Calabria), In Alps, Apennines, Hellenides: Interunion Commission on Geodynamics
Science Report 38 (Cloos, H., Roeder, D., and Schimdt, K. eds), 354-368.

Campbell, J.B. (1987), Introduction to remote sensing. The Guilford Press, New York.

Cardamone, P., Casnedi, R., Cassinis, G., Marcolongo, B., and Tonelli, A. (1976), Study of regional linears of central Sicily by Satellite imagery, Tectonophysics, 33, 81-96.

CASE Team (Ceper, P., Gosen, W., Lyberis, N., Manby, G., PAeCh, H.J., Piepjohn, K., Tessensohn, F. and Thiedig F.) (2001), The evolution of the west Spitsbergen fold-and-thrust belt. In Intra-continental fold belts. Case 1. West Spitsbergen. Geologisches Jahrbuch B 91. (F. Tessensohn ed.) (Stuttgart: Schweizerbart), 733-773.

Cianfarra, P., and SAlvini, F. (2008), Ice cap surface lineaments in the Vostok-Dome C area, East Antarctica. What are they telling us on the East Antarctica craton tectonics? Terra Antarctica Rep. 14, 203-208.

Cianfarra P., Salvini F. (2013a), How old is the youngest tectonics in Svalbard? 11th Ny-Ålesund Science Managers Committee Seminar, National Research Council of Italy, Rome, 9-11 October 2013, Italy, Abstracts, 53, ISSN 2239-5172.

Cianfarra P., Salvini F. (2013b), Intraplate transtensional tectonics in the East Antarctic Craton: insight from buried subglacial bedrock in the Lake Vostok-Dome C region. International Journal of Geosciences 4(9), 1275-1284, doi:10.4236/ ijg.2013.49122.

Dallmann, W.K. (2007), Geology of Svalbard, In Geology of the land and sea areas of northern Europe (eds Sigmond, E., and Roberts, D.) (Trondheim: Geological Survey of Norway) Norges Geologiske Unders $\varnothing$ kelse Special Publication 10, 87-89.

Dallmann, W.K., Andersen, A., Bergh, S.G., Maher, H.D., Jr, \& Онта, Y. (1993), Tertiary fold-and-thrust belt of Spitsbergen Svalbard, Norsk Polarinstitutt Meddelelser, 128, 5-46.

DAvis, G.H.; ReYNolds, S.J. (1996), Structural Geology of Rocks and Regions (2nd ed.), John Wiley \& Sons, Inc, New York (USA), 776 pp, ISBN 0-471-52621-5.

Del Bianco, F., Giglio, F., Langone, L., Miserocchi, S., Aliani, S., GasperinI, L. (2013), Preliminary results from a bathymetric and seismo-stratigraphic survey in the Kongsfjorden, Svalbard Islands, Geophysical Research Abstract, 15, EGU2013-12480.

Dubbini M, Cianfarra P., Casula G, Capra A, Salvini F. (2010), Active tectonics in Northern Victoria Land (Antarctica) inferred from the integration of GPS data and the geologic setting. Journal of Geophysical Research, ISSN: 0148-0227, doi:10. 1029/2009JB007123.

Engen, Ø., Faleide, J.I., and Dyreng, T.K. (2008), Opening of the Fram Strait gateway-a review of plate tectonic constraints. Tectonophysics 450, 51-69.

Faleide, J.I., Gudlaugsson, S.T., Eiken, O., and Hanken, N.M. (1988), Seismic structure of Spitsbergen: implications for Tertiary deformation. Norsk Polarinstitutts Rapportserie 46, 46-50.

Faleide, J.I., Tsikalas, F., Breivik, A.J., Mjelde, R., Ritzmann, O., Engen, Ø., Wilson, J. and Eldholm, O. (2008), Structure and evolution of the continental margin off Norway and the Barents Sea, Episodes 31, 82-91.

Faleide, J.I., Vagnes, E., and Gudlaugsson, S.T. (1993), Late Mesozoic-Cenozoic evolution of the south-western Barents Sea in a regional rift-shear tectonic setting. Marine and Petroleum Geology 10, 186-214. 
Feigl K.L., D.C. Agnew, Y. Bock, D. Dong, A. Donnellan, B.H. Hager, T.A. Herring, D.D. Jackson, T.H. Jordan, R.W. KING, S. Larsen, K.M. Larson, Murray M.H., Zhengkang S., Webb F.H. (1993) Space geodetic measurements of crustal deformation in central and southern California, 1984-1992. J. Geophys. Res. 98, 21677-21712.

Funiciello, R., Parotto, M., Salvini, F., Locardi, E., and Wise D.U. (1977), Correlazione tra lineazioni rilevate col metodo shadow e assetto tettonico nell'area vulcanica del Lazio, Bollettino di Geodesia e Scienze Affini, 36, 451-470.

Gaina, C., Gernigon, L. and Ball, P. (2009), Palaeocene-recent plate boundaries in the NE Atlantic and the formation of the Jan Mayen microcontinent. Journal of the Geological Society 166, 601-616.

Giordano, G., Pinton, A., Cianfarra, P., Baez, W., Chiodi, A., Viramonte, J., Norini, G., Groppelli, G. (2013), Structural control on geothermal circulation in the Cerro Tuzgle-Tocomar geothermal volcanic area (Puna plateau, Argentina). J. Volcanol. Geotherm. Res. 249, 77-94. 10.1016/j.jvolgeores.2012.09. 009.

Gomez H., Kavzoglu T. (2005), Assessment of shallow landslide susceptibility using artificial neural networks in Jabonosa River Basin, Venezuela. Eng Geol 78, 11-27.

Gueguen, E., Sarti, P., Tavarnelli, E., Vittuari, L., and Tomasi, P. (2003), Neotectonic Geological Study and Classical Geodesy Methods Applied to Active Fault Monitoring in Ny Ålesund (Western Svalbard). Proceedings 16th Working Meeting on European VLBI for Geodesy and Astrometry Leipzig, May 9-10, 2003. Edited by Wolfgang Schwegmann and Volkmar Thorandt.

Haeberlin Y., Turberg P., Retiere A., Senegas O., Parriaux A. (2004), Validation of Spot-5 satellite imagery for geological hazard identification and risk assessment for landslides, mud and debris flows in Matagalpa, Nicaragua. Nat. Resour. Canada 35(1), 273-278.

Haas R., Gueguen E., Scherneck H.G., Nothnagel A., and CAMPBELl J., (2000), Crustal motion derived from observations in the European geodetic VLBI network. Earth Planet Space, 52, 759-764.

HARDING, T.P. (1985), Seismic characteristics and identification of negative flower structures, positive flower structures and positive structural inversion. American Association of Petroleum Geologists Bulletin 69, 582-600.

Harland, W.B. (1969), Contribution to the evolution of the North Atlantic region. In North Atlantic: geology and continental drift, a symposium; papers (M. Kay ed.), Tulsa: American Association of Petroleum Geologists, 817-857.

HaRLAND, W.B. (1997), Svalbard's geological frame, In The Geology of Svalbard, Geological Survey Memoir 17, (ed. Harland, W.B.) (The Geological Society London, UK.), 23-44.

HJelle A. (1993). Geology of Svalbard. Polarandbok No. 7. Norsk Polarinstitutt, Oslo.

Huelle, A., Piepjohn, K., Saalmann, K., Ohta, Y., Savigens, O., Thiedig, F., and Dallmann, W. (1999), Geological map of Svalbard 1:100000, sheet A7G Kongsfjorden. Norsk Polarinstitutt Temakart nr. 30 .

Hoввs, W.H. (1904), Lineaments of the Atlantic border region. Geological Society of America Bullettin, 15, 483-506.

Jakobsson, M., Mayer, L.A., Coakley, B., Dowdeswell, J. A., Forbes, S., Fridman, B., Hodnesdal, H., Noormets, R., Pedersen, R., Rebesco, M., Schenke, H.W., Zarayskaya, Y.A, Accettella, D., Armstrong, A., Anderson. R.M., Bienhoff, P., CAmerlenghi,
A., Church, I., Edwards, M., Gardner, J.V., Hall, J.K., Hell, B., Hestvik, O.B., Kristoffersen, Y., Marcussen, C., Mohammad, R., Mosher, D., Nghiem, S.V., Pedrosa, M.T., Travaglini, P.G., and Weatherall, P. (2012), The International Bathymetric Chart of the Arctic Ocean (IBCAO) Version 3.0, Geophysical Research Letters, 39, L12609 doi:10.1029/2012GL052219.

Koch M., Mather P.M. (1997), Lineament mapping for groundwater resource assessment: a comparison of digital Synthetic Aperture Radar (SAR) imagery and stereoscopic Large Format Camera (LFC) photographs in the Red Sea Hills, Sudan. Int J Remote Sens 27(20):4471-4493.

Kumar, A., and Singh, L.S. (2012), Is Isostatic Rebound in Slow Spreading Gakkel Ridge of Arctic Region Due to the Climate Change? A Case Study. International Journal of Geosciences, 3, 339-348.

Leever, K.A., Gabrielsen, R.H., Faleide, J.I., and Braathen, A. (2011), A transpressional origin for the West Spitsbergen foldand-thrust belt: insight from analog modeling. Tectonics 30, TC2014, doi:10.1029/2010TC002753.

Lowell, J.D. (1972), Spitsbergen Tertiary orogenic belt and the Spitsbergen Fracture Zone. Geol. Soc. Am. Bull. 83, 3091-3102.

Lundin, E. and Dore, A.G. (2002), Mid-Cenozoic post-breakup deformation in 'passive' margins bordering the NorwegianGreenland Sea. Marine and Petroleum Geology 19, 79-93.

LyBERIS, N., and MANBY G.M. (1993b), The origin of the West Spitsbergen Fold Belt from geological constraints and plate kinematics: implications for the Arctic. Tectonophysics 224, 371-391.

LyBERIS, N., and MANBy, G.M. (1993a), The West Spitsbergen Fold Belt: the result of Late Cretaceous-Palaeocene GreenlandSvalbard convergence? Geological Journal 28, 125-136.

Maggi M., Rossetti F., Ranalli G., Theye T. (2014), Feedback between fluid infiltration and rheology along a regional ductileto-brittle shear zone: the East Tenda Shear Zone (Alpine Corsica), Tectonics, in press, doi:10.1002/2013TC003370.

Maher H.D. JR., Bergh S.G., BraAthen A., Ohta Y. (1997), Svartfjella, Eidembukta, and Daudmannsodden lineamentDecoupled orogen-parallel motion in the crystalline hinterland of Spitsbergen's fold-thrust belt. Tectonics 16, 88-106.

Maher, H.D., Craddock, C. (1988). Decoupling as an alternate model for transpression during the initial opening of the Norwegian Greenland Sea. Polar Research 6, 137-140.

MazZarini F., and Salvini, F (1994), Tectonic blocks in North Victoria Land (Antarctica): Geological and structural constraints by satellite lineament domain analysis, Terra Antarctica, 1, 74-77.

Molnar, P., H. J. Anderson, E. Audoine, D. Eberhart-Phillips, K. R. Gledhill, E. R. Klosko, T. V. McEvilly, D. OKaya, M. K. Savage, T. Stern, and F. T. Wu, (1999). Continuous Deformation Versus Faulting through the Continental Lithosphere of New Zealand. Science, 286, 516-519.

Mitchell, B.J., Bungum, H., Chan, W.W., Mitchell, P.B. (1990), Seismicity and present-day tectonics of the Svalbard region, Geophys. J. Int. 102, 139-149.

Mitrovica, J. X., Davis, J. L., and Shapiro, I. I. (1994), A spectral formalism for computing three-dimensional deformations due to surface loads, 2. Present day glacial isostatic adjustment, J. Geophys. Res., 99, 7075-7101.

Morelli M., Piana F. (2006), Comparison between remote sensed lineaments and geological structures in intensively uncultivated hills (Moanferrato and Langhe domains, NW Italy). Int J Remote Sens 26(7), 1463-1475. 
Mosar, J., Torsvik, T.H. and the BAT Team (2002), Opening of the Norwegian and Greenland seas: plate tectonics in mid Norway since the Late Permian, In BATLAS-mid Norway plate reconstructions atlas with global and Atlantic perspectives (E.A. Eide ed.) (Trondheim: GeologicalSurvey of Norway), pp. 48-59.

Norini G., Groppelli G., Caprac L., De Benid E. (2004), Morphological analysis of Nevado de Toluca volcano (Mexico): new insights into the structure and evolution of an andesitic to dacitic stratovolcano. Geomorphology 62, 47-61.

Pal S.K., Majumdar T.J., Bhattacharya A.K. (2006), Extraction of linear and anomalous features using ERS SAR data over Singhbhum Shear Zone, Jharkhand using fast Fourier transform. Int J Remote Sens 27(20), 4513-4528.

Pardo, N., Macias, J.L., Giordano, G., Cianfarra, P., Bellatreccia, F., Avellán, D.R. (2009), The 1245 yr BP Asososca maar eruption: the youngest event along the Nejapa-Miraflores volcanic fault, Western Managua, Nicaragua, J. Volcanol. Geotherm. Res. 184(3-4), 292-312. doi:10.1016/j.jvolgeores.2009.04.006.

Pischiutta, M., Salvini, F., Fletcher, J., Roveldi, A., Ben-Zion, Y. (2012), Horizontal polarization of ground motion in the Hayward fault zone at Fremont, California: dominant fault-high-angle polarization and fault-induced cracks, Geophys. J. Int. 188(3), 1255-1272. doi:10.1111/j.1365-246X.2011.05319.x.

Pischiutta, M., Anselmi, M., Cianfarra, P., Rovelli, A., Salvini, F. (2013), Directional site effects in a non-volcanic gas emission area (Mefite d'Ansanto, southern Italy): Evidence of local transfer fault transversal to large $N W-S E$ extensional faults? J. Phys. Chem. Earth, in press, doi:10.1016/j.pce.2013.03.008.

RAmsay, J. G., and Huber, M. I. (1983), The techniques of modern structural geology, Vol. 1, Strain analysis. Academic Press, London, $307 \mathrm{p}$.

Rossetti, F., Storti F., and SAlvini, F. (2000) Cenozoic noncoaxial transtension along the western shoulder of the Ross Sea, Antarctica and the emplacement of McMurdo dyke arrays, Terra Nova 12, 60-66.

SaAlmann, K., and Thiedig, F. (2001), Tertiary West Spitsbergen fold and thrust belt on Brøggerhalvøya, Svalbard: Structural evolution and kinematics, Tectonics, 20(6), 976-998.

Salvini, F., Ambrosetti, P.L., Conti, A.M., Carraro, F., Funiciello, R., Ghisetti, A., Parotto, M., Praturlon, A., Vezzani, L. (1979), Tentativi di correlazione tra distribuzioni statistiche di lineamenti morfologici ed elementi di neotettonica, Contr. Prel. Carta Neotettonica d'Italia, pubbl. n. 51 P.F. Geodinamica, CNR.

SAlvini, F., Billi, A., and Wise, D.U. (1999), Strike-slip faultpropagation cleavage in carbonate rocks: the Mattinata Fault Zone, Southern Apennines, Italy, Journal of Structural Geology, 21, 1731-1749.

Skjelkvale, B.L., Amundsen, H.E.F., O’Reilly, S.Y., Griffin, W.L., and GJELSVIK, T. (1989), A primitive alkali basalt stratovolcano and associated eruptive centres, Northwestern Spitsbergen: Volcanology and tectonic significance, Journal of Volcanology and Geothermal Research, 37, 1-19.
Solomon S., Ghebreab W. (2006), Lineament characterization and their tectonic significance using Landsat TM data and field studies in the central highlands of Eritrea. J Afr Earth Sc 46(4), 371-378.

Soudarin L., Crétaux J.F., Cazenave A. (1999), Vertical crustal motions from the DORIS space-geodesy system. Geophysical Research Letters, 26, 9.

SRIVAStava, S.P. (1978), Evolution of the Labrador Sea and its bearing on the early evolution of the North Atlantic. Geophysical Journal of the Royal Astronomical Society 52.

Storti F., Holdsworth R.E., SAlvini F. (2003), Intraplate strikeslip deformation belts. Geological Society, London, Special Publications, 210, 1-14.

Storti, F., Salvini, F., Rossetti, F., Morgan, J.P. (2007), Intraplate termination of transform faulting within the Antarctic continent, Earth and Planetary Science Letters, 260, 115-126.

Talwani, M., and Eldholm, O. (1977), Evolution of the Norwegian-Greenland Sea, Geol. Soc. Am. Bull. 88, 969-999.

Tessensohn, F. and Piepjohn, K. (2000), Eocene compressive deformation in Arctic Canada, North Greenland and Svalbard and its plate tectonic causes. Polarforschung 68, 121-124.

Tolgensbakk, J., Sollid J.L. (1987), Kvadehuksletta, Geomorfologi Og Kvartærgeologi 1:10000. Norsk Polarinstitutt Temakart 8, Department of Geography, University Of Oslo.

TorsviK, T.H., Mosar, J., and EIDE, E.A. (2001), CretaceousTertiary geodynamics: A North Atlantic exercise. Geophys. J. Int, 146, 850-866.

Turcotte, D. L., and Schubert, G. (2002), Geodynamics, 2nd ed., 456 pp., Cambridge Univ. Press, Cambridge, U.K.

VÅgNes, E., and AmundSEn, H.E.F. (1993), Late Cenozoic uplift and volcanism on Spitsbergen: Caused by mantle convection?, Geology, 21, 251-254.

Wakabayashi, J. (1999), Distribution of displacement on and evolution of a young transform fault system: the northern San Andreas fault system, California, Tectonics, 18, 1245-1274.

Wise, D.U. (1967), Previously unreported fracture systems over vast areas of the Appalachians, U.S. Cordillera and Europe, Trans. AGU, 48, 214.

WiSE, D.U. (1969), Pseudo-radar topographic shadowing for detection of sub-continental sized fracture systems, Proceedings of the Sixth International Symposium in Remote Sensing of Environment, Univ. of Michigan, 603-615.

WisE, D.U. (1982), Linesmanship and the practice of linear geoart, Geol. Soc. Am. Bull, 94, 886-888.

Wise, D.U., Funiciello, R., Parotto, M., Salvini, F. (1979), Domini di lineamenti e fratture in Italia, Pubblicazione dell'Istituto di Geologia e Paleontologia dell'Università degli Studi di Roma, n. 42, 1-53.

Wise, D.U., Funiciello, R., Parotto, M., Salvini, F. (1985), Topographic lineament swarms: clues to their origin from domain analysis of Italy, Geol. Soc. Am. Bull. 96, 952-967. 